Comparative Philosophy Volume 8, No. 2 (2017): 90-105

Open Access / ISSN 2151-6014

www.comparativephilosophy.org

\title{
THE SELF: KIERKEGAARD AND BUDDHISM IN DIALOGUE
}

\author{
DAVID WISDO
}

\begin{abstract}
Is it possible for there to be a fruitful dialogue between Søren Kierkegaard and Buddhists regarding the understanding of the self? In this paper, I explore the possibilities for such a dialogue by first discussing the rejection of substantialism shared by Kierkegaard and Buddhists. Next, although many Buddhists accept a reductionist account of the kind found in the Abhidharma tradition, Madhyamaka thinkers such as Nāgārjuna and Candrakirti are well-known for offering an account of the self, based on the notion of emptiness (s'ünyatā), which resembles in some ways the account of the self that is proposed by Kierkegaard's pseudonym Anti-Climacus in The Sickness Unto Death. Third, I discuss Jonardon Ganeri's performativist theory of the self and his suggestion that this view, originally developed by Candrakirti, informs the view of the self which is developed by Kierkegaard's pseudonym Johannes Climacus in the Concluding Unscientific Postscript. I conclude by exploring how Ganeri's perfomativist theory of the self can illuminate recent attempts by both Buddhist and Kierkegaard scholars to articulate their accounts of the self by an appeal to narrative.
\end{abstract}

Keywords: Anthony Rudd, Buddhism, Candrakirti, emptiness, Jonardon Ganeri, Kierkegaard, Marya Schechtman, Nāgärjuna, narrative, no-self, performativist theory of the self, self

\section{INTRODUCTION}

When one examines the basic teachings of Buddhism or the writings of the Danish philosopher Søren Kierkegaard, it becomes clear in both cases that questions about the nature of the self are of decisive spiritual importance. For Buddhists, on the one hand, the notion of the self comes under critical scrutiny. Their claim is that the idea of a permanent, unchanging self is an illusion. Since this illusion is the source of the craving that underlies the spiritual disease of suffering (duhkha), the goal is to overcome this illusion through Buddhist practice. For Kierkegaard, on the other hand, it is precisely the loss of the self which is the source of the disease characterized by

WISDO, DAVID: Professor of Philosophy, Columbus State University, Georgia, USA. Email:wisdo_david@columbusstate.edu 
his pseudonym Anti-Climacus as the "sickness unto death." The cure, says Kierkegaard, does not involve viewing the self as an illusion to be overcome. Instead, Kierkegaard recommends the spiritual practice he calls "edification" which aims to build up (at bygge op) the self. Finally, because Kierkegaard views this spiritual goal of edification from an explicitly Christian perspective, he does not understand this practice of "building up" the self as an autonomous activity but rather as a response to God's ongoing invitation to realize oneself as a creature dependent upon God.

I would like to argue that despite their differences, Kierkegaard and Buddhists share some basic assumptions about the self. First, when Buddhists speak of the self as an illusion or when Kierkegaard says that the self is not simply a "given" but rather something that must be "built up," they are rejecting a metaphysical view that regards the self as a simple, static substance. In the case of Kierkegaard, this might be understood as a rejection of the kind of substantialism defended by René Descartes; whereas in the case of Buddhism this can be understood as a rejection of the idea of a permanent and unchanging self (ätman). More interesting, I shall argue, is that something similar to the Buddhist notion of emptiness (śünyatā), articulated and defended by Mahayana Buddhists such as Nāgārjuna and Candrakīrti, informs Kierkegaard's understanding of the self as it is presented by his pseudonym AntiClimacus in the The Sickness Unto Death. To develop this idea in more detail, I will discuss Jonardon Ganeri's performativist theory of the self as well as his suggestion that this kind of approach, inspired by Candrakīrti, also informs the account of the self as it is presented by Kierkegaard's pseudonym Johannes Climacus in the Concluding Unscientific Postscript. Finally, I will suggest that Ganeri's performativist theory, as it pertains to both Buddhist and Kierkegaardian views of the self, can be further developed in light of recent narrative theories of the self that have been appropriated by Buddhist and Kierkegaard scholars.

\section{AGAINST SUBSTANTIALISM}

There is a long-standing tradition among philosophers to think of individuals as either being or having a self, regarded as a simple unchanging substance that constitutes the individual's essential nature. What is it, after all, that allows me to identify myself as the same individual over time-yesterday, today, and tomorrow? What is it that explains why I care about my past and my future? Why do I feel moral responsibility for past misdeeds and resolve to avoid them in the future? Among Western thinkers, Plato is well-known for defending the idea of a simple, unchanging, and immortal soul in the Phaedo. A similar view is later affirmed and defended by René Descartes, whose name now informs how we speak of this substantialist view whenever we refer, for example, to a "Cartesian ego." Similarly, before and after the time of the Buddha, philosophers and religious thinkers in India also developed and affirmed a 
substantialist notion of the self, introduced in the Upanișads, which they spoke of as ätman. ${ }^{1}$

Although there are many reasons why one might reject such a substantialist view of the self, for Buddhists the motivation has always been largely soteriological. The Four Noble Truths begin by identifying our primary existential malady as suffering $(d u h k h a)$ : a pervasive disease that arises from desire, aversion and a fundamental ignorance as to the nature of reality, what Jay Garfield terms a "primal confusion" (Garfield 2015, 9-11). In addition to a refusal to see that all things are impermanent and conditioned, we cling to the mistaken idea of an enduring and substantial self. As it turns out, it is clinging to this mistaken idea of a substantial self which is largely responsible for suffering. Fortunately, the Third Noble Truth points to a cure: the cessation of suffering (nirvāna). The realization that the substantial self is an illusion leads to the extinction of the desire and aversion that fuels suffering. Finally, this cure is found in the Fourth Noble Truth, a path that presents a therapeutic regimen involving morality, meditation and the cultivation of wisdom.

Of course, if the extinction of suffering requires that we give up the mistaken substantialist view of the self, the obvious question is: what is the right view? The standard analysis given in early traditions and later developed with much rigor and sophistication in the Abhidharma literature involves a reductionist account (Siderits 2007, 32-68). The claim is that the self is a composite of five aggregates (skandhas) that are impermanent and always changing. In addition to the bodily component, rüpa, there are four mental components: feeling (vedanā), that is, the sense that a mental state is pleasant, painful or neutral, perception (samjjūa ), volition (samskāra) and consciousness (vijñanna). What is missing is any reference to a substantial unchanging self and this, of course, is the point. Without examining the details of the arguments used to support this reductionist picture (see Siderits 2007, 37-50), the Buddhist conclusion is clear. There is no basis for the erroneous and unwholesome view that individuals are substantial selves.

When we turn to Kierkegaard's writings, especially The Sickness Unto Death attributed to his pseudonym Anti-Climacus, we find another interesting antisubstantialist view of the self. Once again, the account here does not aim to address technical metaphysical concerns for their own sake. Like Buddhists, Anti-Climacus's discussion of the self is motivated mainly by ethical and soteriological concerns. Here is the first part of his now classic but perplexing characterization of the self:

The human being is spirit. But what is spirit? Spirit is the self. But what is the self? The self is a relation which relates to itself, or that in the relation which is its relating to itself. The self is not the relation but the relation's relating to itself. A human being is a synthesis of the infinite and the finite, of the temporal and the eternal, of freedom and

\footnotetext{
${ }^{1}$ The doctrine of ätman which appears in the Upanișads not only involves the idea of an unchanging substantial self but also the idea that this unchanging substantial self is identical to the universal self or Brahman. For a detailed discussion of atman and the brahmanical context in which the idea arises see Williams, Tribe and Wynne (2012, 4-15).
} 
necessity. In short a synthesis. A synthesis is a relation between two terms. Looked at in this way a human being is not yet a self.

In a relation between two things the relation is the third term in the form of a negative unity, and the two relate to the relation, and in the relation to that relation; this is what it is from the point of view of soul for soul and body to be in relation. If, on the other hand, the relation relates to itself, then this relation is the positive third, and this is the self (Kierkegaard 1989, 43).

Despite the voluminous commentary generated by this passage, ${ }^{2}$ it is worth reminding ourselves of its obvious features. First, although the two initial claims - that "the human being is spirit" and "spirit is the self" (Kierkegaard 1989, 43) —might suggest that Anti-Climacus intends to develop a traditional substantialist account of the self, the remainder of the passage leaves no doubt that this is precisely the view he aims to reject. ${ }^{3}$ The self is neither a substance nor an object of any kind. Instead, AntiClimacus provides the surprisingly original characterization of the self as an ongoing and dynamic synthesis involving three "existential" dimensions, each of which involves contrasting opposites: the infinite and the finite, the temporal and the eternal, and freedom and necessity. Some commentators ${ }^{4}$ interpret these contrasting opposites in such a way as to express the relation between the body and the soul mentioned by Anti-Climacus - the body, involving finitude, temporality, and necessity; and soul, involving the infinite, the eternal and freedom. Again, although such an analysis might suggest a kind of substance dualism, neither the body nor the soul should be understood as a static Cartesian substances. Rather the point is to suggest that the self emerges from the dynamic tension between these opposing poles. Not only is the self, as necessity, a limited, temporal being; the self, as freedom, possesses an eternal dimension which is its possibility for realizing itself. Moreover, Anti-Climacus refers to these poles as involving a relation; "a relation which relates to itself, or that in the relation which is its relating to itself" (Kierkegaard 1989, 43). And just in case we might be tempted to construe this relation as static, Anti-Climacus quickly reminds us that the self is "the relation's relating to itself" (Kierkegaard 1989, 43); that is, the self is an activity that constitutes itself in this relation. In short, the self just is the activity of becoming a self.

Like the Buddhist then Anti-Climacus presents an analysis which does away with the metaphysical notion of a static substantial self. Although the specifics of the

\footnotetext{
${ }^{2}$ The dense and enigmatic nature of the passage has led one Kierkegaard scholar to comment that "this is not the gobbledygook it seems to be, though there is good reason why it must seem so" (Mackey 1971, 135). Other interpretations of this difficult text include Dunning (1985, 215-17), Elrod (1975, 29-32), Hannay (1982, 190-94), Malantschuk (1971, 343-47), and Taylor (1980, 166-72). For more recent scholarship focusing on this passage see Davenport (2013, 233-38), Dreyfus (2008, 12-23), Mooney (1996, 89-93), Rudd (2012, 40-43), and Stokes (2010, 61-69) and (2015, 143-47).

${ }^{3}$ With some exceptions, e.g. Jamie Turnbull (2011), most contemporary Kierkegaard scholars interpret Kierkegaard as rejecting the idea that the self is a substance. See e.g. Davenport $(2013,234)$, Grøn $(2004,131)$, Rudd $(2012,41)$, and Stokes $(2010,66)$ and $(2015,144)$.

${ }^{4}$ See, e.g. Dreyfus $(2008,13)$ and Davenport $(2013,235)$.
} 
analysis differ, both Anti-Climacus and the Buddhist agree that the self must be understood primarily in terms of change. Anti-Climacus adds to his account a multidimensional analysis of the self that characterizes this change as activity, whose goal is the constitution of the self. In short, for Anti-Climacus there is no self apart from its own ongoing and dynamic activity of synthesis which Patrick Stokes nicely sums up as a task:

Anti-Climacus holds that selfhood is not a stable 'given,' such that membership in the human race automatically confers that status of selfhood... the self is fundamentally a task, something we are supposed to become, not something we find ourselves as being, and something we can easily cease to be (Stokes 2010,63).

One might object to this kind of account for the simple reason that the selfconstitutive activity described by Anti-Climacus would seem to presuppose a substantial self. After all, the objection might go, how can there be such activity unless there is a substantial self to perform it? As a first response to this objection, it is important to keep in mind that Anti-Climacus is not denying that there is a self. What he is denying is that the self is to be understood in a certain way; namely as a simple static substance. The view he is affirming is that the self just is the activity of constituting itself as the ongoing synthesis of the finite and infinite, the temporal and eternal, and freedom and necessity.

Unfortunately, this response to the first objection gives rise to a second. For even if the Kierkegaardian self is not a substance in the Cartesian sense, there does seem to be something strange about saying that the self is an activity whereby it creates itself. The claim that the self makes itself through its own activity does not seem to make sense. How can the self be both the source and product of its activity? Interestingly, Kierkegaard himself is aware of the paradox. In an earlier upbuilding discourse, originally published in 1843, entitled To Gain One's Soul in Patience he makes the following observation:

But if a person possesses his soul, he certainly does not need to gain it, and if he does not possess it, how can he gain it since the soul itself is the ultimate condition that is presupposed in every acquiring, consequently also in gaining the soul. Could there be a possession of that sort, which signifies precisely the condition of being able to gain the same possession (Kierkegaard 1990, 163-64)?

Moreover, in his attempt to solve the paradox, he includes a description of the soul that anticipates the description of the self in The Sickness Unto Death:

The soul is the contradiction of the temporal and the eternal, and here, therefore, the same thing can be can possessed and the same thing gained at the same time. Indeed, what is more, if the soul is this contradiction, it can only be possessed in such a way that it is gained and gained in such a way that it is possessed (Kierkegaard 1990, 164). 
Is it possible to say anything more in attempting to resolve this paradox? What does it mean to say of the soul or of the self that "it can only be possessed in such a way that it is gained and gained in such a way that it is possessed" (Kierkegaard, 1990, 164)? Fortunately, this question has been examined in detail by the contemporary philosopher Christine Korsgaard who has identified this worry as the "paradox of self-constitution." She expresses the paradox as follows:

It is as a possessor of personal or practical identity that you are the author of your actions, and responsible for them. And yet at the same time it is in choosing your actions that you create your identity. What this means is that you constitute yourself as the author of your actions in the very act of choosing them. I am fully aware that this sounds paradoxical. How can you constitute yourself, create yourself, unless you are already there? Call this the paradox of self-constitution (Korsgaard 2009, 20).

How does Korsgaard propose to resolve this paradox? According to Korsgaard, the paradox disappears once we realize that the process of self-constitution is analogous to the process of living. Appealing to Aristotle, Korsgaard first observes that the process of living is best understood as the organism's activity of making itself into itself. Next, she observes that the form of life distinctive of human beings involves rational activity. Finally, if this rational activity is the self-conscious activity involved in the construction of personal identity, then "being a person, like being a living thing, is being engaged in the activity of self-constitution" (Korsgaard 2009, 42). I would add, moreover, that just as we do not need to appeal to some mysterious substance - a Bergsonian élan vital - to explain life, in the same way we do not need some mysterious Cartesian substance to explain the self as a self-constitutive activity.

At this point we are in a better position to identify places of agreement and disagreement between Kierkegaard and Buddhists. First, although Kierkegaard agrees with Buddhists in rejecting a substantialist account of the self, he would likely not accept as an alternative their reductionist theory, nor would he accept versions more familiar to western thinkers, such as David Hume's "bundle theory." This is because he insists that the cultivation of a self, what he calls edification or "building up" (opbyggelse) is the aim of spiritual practice. In fact, contrary to the Buddhist who says that the only way to overcome suffering is to reject the self as an illusion, AntiClimacus affirms it. So here we do have a real conflict between Buddhist and Kierkegaardian views of the self, at least on the question of whether it's good to cultivate one. The Buddhist insists that because belief in the self is an unwholesome illusion that leads to suffering, it must be subjected to a reductionist analysis. Kierkegaard's Anti-Climacus, however, would reject any kind of reductionist analysis insofar as it undermines his primary aim of affirming the edification of the self.

There is one more crucial point made by Anti-Climacus in the opening sections of The Sickness Unto Death which is bound to complicate matters. Given his explicitly Christian perspective, we should not be surprised to discover that in addition to affirming the self as a task to be achieved, Anti-Climacus insists this activity is not autonomous. As he puts it, because the self is a derived relation constituted by God, it 
can despair in two ways: either by wanting to get rid of itself or by wanting in defiant despair to be itself. Throughout the remainder of The Sickness Unto Death then AntiClimacus provides detailed diagnoses of these two pathological conditions. In the first case, an individual can despair either by forgetting that it is a self or by trying to lose itself in a wide variety of ways. In the second case, since the individual is a creature dependent upon God, one also suffers from despair to the extent that one aims to become a self in an independent and autonomous fashion, which AntiClimacus characterizes as defiance. In more theological language then the task of becoming a self involves an ongoing response to God's grace. Ultimately, says AntiClimacus, the only cure for despair is when "in relating to itself and in wanting to be itself, the self is grounded transparently in the power that constituted it" (Kierkegaard 1989, 44).

\section{FROM REDUCTIONISM TO THE MIDDLE WAY}

Up until this point our comparison of Kierkegaard and Buddhism has been based on the kinds of reductionist accounts of the self that are found in the early Buddhist tradition. Unfortunately, if we were forced to limit our discussion of Kierkegaard and Buddhism to these early reductive analyses, we might have to admit that we have reached a dead end. It turns out, however, that there is another path open for exploration. Over time a new idea appeared in the scriptural tradition of Mahayana Buddhism known as the Perfection of Wisdom (prajñapāramitā) literature. ${ }^{5}$ This is the idea of śünyata or emptiness. As we shall see, this new idea provides Mahayana Buddhist philosophers such as Nāgārjuna and Candrakīrti with a framework for criticizing earlier reductionist accounts of the self and for developing a new philosophical approach that extends the idea of no-self in a radical way to everything that exists. More importantly, for our purposes it also opens new possibilities for comparing Kierkegaardian and Buddhist views of the self.

Before turning to these issues, however, it is important to mention that the reductionist approach to the self that is characteristic of early Buddhism culminated in the Abhidharmikas which radicalized this way of thinking by extending the reductive analysis to all phenomena, not just selves. According to this more radical reductionism, everything can be analyzed by breaking phenomena down into dharmas, which several philosophers have characterized as tropes, i.e. property particulars (Siderits 2007, 115; Garfield 2015, 45). According to one school, although what we experience as tables and chairs appear to be relatively stable and permanent, close analysis reveals that they can be reduced to more fundamental phenomena which, though momentary, are said to possess their own intrinsic nature (svabhāva). Thus, the Abhidharma approach can be viewed as bringing the reductionist project to

\footnotetext{
${ }^{5}$ For historical details on the emergence of Mahayana thought and the concept of emptiness (śünyata) in the Perfection of Wisdom (Prajñāpāramitā) Sūtras see Williams (2009, 45-62) and Williams, Tribe and Wynne (2012, 98-104). The short and well-known Heart Sütra (Hṛdayam Sütra) in Conze (1973, 140-41) provides a concise presentation of the teaching.
} 
its logical conclusion. In the final analysis, according to the Abhidharmikas, we need to distinguish the ultimate truth about things, revealed by a thoroughgoing reduction of everything into dharmas, from the conventional truth of ordinary everyday experience. In short, we must to ready to acknowledge that only dharmas are ultimately real and that everything else, including selves, are at best useful fictions.

Given this radical kind of reductionism, it should come as no surprise that both Buddhists and outside critics expressed concern over its troubling implications. Among Buddhists, the most thoroughgoing critique can be found in the Madhyamaka or Middle Way developed and defended by Nāgārjuna and his commentators, most notably Candrakirti. According to the Madhyamka, the reductionist project of the Adhidharma, far from vindicating the central teaching of dependent origination (pratītya-samutpāda) undermines it by positing an unacceptable ontological dualism between composites that are subject to dependent origination, and dharmas which, possessing intrinsic nature, are said to be independent. Given this ontological dualism, the reductionist is forced to accept a troubling conclusion about conventional existence. The problem, the Mādhyamikas argue, is that by reducing conventional existence to a mere fiction, the Adhidharma approach slides into nihilism.

What then is the solution? To vindicate conventional existence, the Mādhyamikas insist that all phenomena are empty (śünyatā) of inherent existence. But what does this mean? First, we need to guard against the mistaken conclusion that this is just another, even more radical form of nihilism. To say everything is empty of inherent existence is not to make the nihilistic claim that nothing exists. The aim rather is to explain how things exist. In saying that everything is empty of inherent existence, Mādhyamikas are saying that the only way anything can exist at all is interdependently with all things. As Jay Garfield sums it up with reference to Nāgārjuna's analysis of emptiness: "the only reality anything can have is conventional reality. To be real on this understanding is hence not to possess, but to lack, ultimate reality" (Garfield 2015, 65).

\section{A PERFORMATIVIST THEORY OF THE SELF?}

The question now is this: What implications might the Madhyamaka view of emptiness have for our understanding of selves; and how might this account advance the dialogue between Kierkegaard and Buddhism on the self? Can the Madhyamaka view of emptiness provide a framework for developing and defending an alternative account of the self? One interesting approach in this regard has been suggested by Jonardon Ganeri who, inspired by Nāgārjuna's commentator Candrakīrti, proposes what he calls a performativist theory of the self (Ganeri 2012, 183-213). To motivate the theory, Ganeri considers the challenge expressed by Nāgārjuna in chapter 18 of The Fundamental Wisdom of the Middle Way (Mülamadhyamakakārikā) regarding how to understand the relation between the self and the skandhas or aggregates. In this very condensed argument, Nāgārjuna rejects two possibilities:

If the self were the aggregates, 
It would have arising and ceasing (as properties).

If it were different from the aggregates,

It would not have the characteristics of the aggregates (Garfield 1995, 245).

How, according to Ganeri, does Candrakīrti understand this dilemma? On the one hand, if the self consists in the aggregates, it would constantly be arising and ceasing. The unacceptable result would be a proliferation of selves coming in and out of existence (Ganeri 2012, 197). If, on the other hand, the self was something completely different from the aggregates, this could not explain our sense of owning our experiences and would be, in Ganeri's words, "an idle wheel" (Ganeri 2012, 195 96). But if the self is neither reducible to the aggregates, nor separate and distinct from them, how exactly should we understand the dependence relation? Ganeri argues that Candrakīrti provides the key by suggesting that this relation is one of "appropriating" (upādāna). Instead of mistakenly thinking of the self as an object or of the word "self" as a referring term, Ganeri suggests that we follow Candrakìrti for whom the self is better understood as a performative process. Ganeri highlights this point by citing chapter 6 verses 162-3 of Candrakirti's Introduction to the Middle Way (Madhyamakāvatāra):

And thus the self-dependent on the aggregates, the elements, and the senses as they are in daily life - is thought of as the appropriator of the same; these are the objects appropriated, the self their appropriator. The self is not a real, existent thing, and thus it is not constant, for it has no birth or ending. Attributes like permanence do not apply to it, and it is not, nor is it other than, the aggregates (Candrakirti 2002, 6.162-3; cited by Ganeri, 2012, 199).

One might still conceivably object to this account insofar as it appears to reintroduce surreptitiously the very thing it seeks to deny; namely, the idea of a substantial self. After all, if one wants to say that the self just is a process of appropriation, doesn't this mean that the appropriator doing the appropriating must be a substance? Notice that this worry resembles the one raised earlier in our discussion of Anti-Climacus, where the issue was whether there can be self-synthesizing activity-involving the infinite and the finite, the temporal and the eternal, and freedom and necessitywithout a substantial self. Ganeri's own solution, as mentioned above, appeals explicitly to a claim about the semantics of the word "I" and his insistence that the word should not be understood as a referring term. However, another possible solution to this "paradox of self-appropriation" is to appeal once again to Christine Korsgaard's solution to the paradox of self-constitution (Korsgaard 2009, 42). As we have seen in our earlier discussion, just as we do not need a permanent independent substance to explain the process by which living things make themselves, so too there is no need for a permanent independent substance to explain how the self can create itself through the process of self-appropriation.

Given Ganeri's claim that Candrakīrti is offering a performativist theory of the self, the next question is whether this suggestion could possibly be brought into constructive dialogue with Kierkegaard's understanding of the self. Interestingly, in 
his attempt to muster independent support for this performativist account, Ganeri enlists several western thinkers whom he sees as supporting this view, ranging from John Locke and William James to Elizabeth Anscombe and Simon Blackburn (Ganeri 2012, 200-1). For our purpose, what is most striking is a footnote in which Ganeri explicitly makes the connection with Kierkegaard by suggesting that the performativist theory of the self seems to be affirmed by his pseudonym Johannes Climacus in the Concluding Unscientific Postscript. The passages he cites are specifically those in which Johannes Climacus discusses truth and refers to truth understood subjectively first as "an objective uncertainty, held fast through appropriation with the most passionate inwardness" (Hong 1992, 202; cited by Ganeri 2012,201 ) and later as a truth that is "the self-activity of appropriation" (Hong 1992, 202; cited by Ganeri 2012, 201). Ganeri himself does not develop his intriguing idea in further detail, so it might be worth our while to see where his suggestion might lead.

First, we need to examine in a bit more detail what Ganeri means by a performativist theory of the self. In developing this theory, inspired by Candrakīrti's commentary, Ganeri is particularly interested in how we use words such as "I" and "mine." After noting that such words are not to be understood as referring to an object or a thing, Ganeri argues that Candrakīrti is offering a "use-explanatory account" of the word, which he characterizes as follows:

The utterance of 'I' serves an appropriative function, to claim possession of, to take something as one's own. The appropriation in question is to be thought of as an activity of laying claim to, not the making of an assertion of ownership. Grammatical form notwithstanding, the avowal or self-ascription of a mental state, 'I have a pain', is not a two-place relation between me and my pain; nor is it like a club's having members, or a tree's having roots... When I say 'I am in pain,' I do not assert ownership of a particular kind of painful experience; rather I lay claim to the experience within a stream. This is a performativist account of the language of the self, in which 'I' statements are performative utterances, and not assertions... (Ganeri 2012, 200).

Ganeri himself chooses to make the connection with Kierkegaard by citing Johannes Climacus's Concluding Unscientific Postscript; but I would like to suggest that his performativist theory of the self can also help shed light on Anti-Climacus's famously obscure and enigmatic account of the self which we discussed earlier. When, for example, Anti-Climacus speaks of the self in The Sickness Unto Death, we have seen that he wishes to understand the self not as a substance, but rather as a synthesizing activity. Appealing now to Ganeri's performativist theory, not only can we speak of the self's activity as "the relation's relating to itself" (Kierkegaard 1989, 43), we can also speak of it as a performative activity wherein I lay claim-to use Ganeri's specific phrase - to the continuing synthesis of the infinite and the finite, the temporal and the eternal, and freedom and necessity.

Of course, when making these connections we need to take care. Although Ganari uses the word "appropriation" to describe both Candrakirti's understanding of "selfing" and Johannes Climacus's view of the self-constitution in the Postscript, the 
different contexts are sure to complicate matters. So when he discusses "appropriating" (upādāna) as Candrakīrti understands it, Ganeri emphasizes that the classic Buddhist context for the word upādana and its cognates makes reference to fuel, as in fuel for a fire. Referring to another passage from Candrakīrti, for example, Ganeri reminds us that the fuel is what is appropriated - namely the five aggregatesand the self is the constructive activity of appropriation (Ganeri 2012, 199). Moreover, as Ganeri also points out, the Buddhist understands the word as carrying the negative connotations of "grasping, clinging, addiction" (Edgerton 1953; cited by Ganeri 2012, 198). Finally, and most importantly, when we remember that the goal of the path is nirvana - to put out the fire-we will appreciate the urgency of undertaking the appropriate spiritual practices to stop feeding it. In other words, if appropriation or "laying claim" to the stream is what fuels the fire of samsara, then we need to embark upon the Buddhist path and stop feeding it to put out the activity of self-appropriation (Ganeri 2012, 202-3).

In the world according to Kierkegaard, of course, things are very different. First, if we follow Ganeri's suggestion that Kierkegaard, like Candrakīrti, sees "selfing" as an activity of appropriation, we must first remember that the Danish word tilegnelse translated by both the Hongs and Alasdair Hannay as "appropriation" is quite straightforward. The word does not have special associations as upādāna does; nor are there the negative connotations of "grasping, clinging and addiction." In addition, for Kierkegaard this activity of appropriation, so far from being the source of spiritual illness, holds instead the promise of spiritual recovery. For when we ask what is being appropriated for Kierkegaard in this activity of "selfing" we discover not five aggregates but rather the continuing activity of synthesizing the infinite and the finite, the temporal and the eternal, and freedom and necessity. Finally, as already mentioned, this task of appropriation is not autonomous. Throughout The Sickness unto Death Anti-Climacus reminds us that a self that defiantly asserts itself as an independent being is a self in despair. For this reason, Anti-Climacus emphasizes the Christian idea that the appropriation process involved in becoming a self is always dependent on God.

\section{APPROPRIATION, PERFORMANCE AND NARRATIVE}

When we ask what might be the best way to articulate and develop this kind of performativist theory of the self, whether along Buddhist or Kierkegaardian lines, we will discover resources already available in the growing literature focusing on self and narrative. For several decades, ever since the publication of works such as Alasdair MacIntyre's After Virtue, Charles Taylor's Sources of Self and Paul Ricoeur's three volume Time and Narrative, there has been a growing interest among philosophers asking how narrative can provide a framework for addressing a host of issues, ranging from traditional metaphysical questions concerning personal identity to normative questions concerning ethics and selfhood. Interestingly, a growing number of Kierkegaard scholars such as John Davenport and Anthony Rudd have answered MacIntytre's infamous critique of Kierkegaard in After Virtue with the 
claim that Kierkegaard himself can best be understood as a narrativist (Davenport and Rudd 2002). At the same time, the appeal to narrative has not been limited to Kierkegaard scholars. Thinkers focusing on Buddhist philosophy such as Jay Garfield have also discussed the extent to which narrative might be helpful in elucidating Buddhist views on issues such as selfhood and ethics. Although it is impossible to do justice to this rich area of reflection in this short essay, a brief overview of the basic ideas will show how an appeal to narrative might provide a helpful way to develop Ganeri's performativist theory of the self.

One very influential narrative theory of the self which appears to have much in common with Ganeri's performativist account has been developed by Marya Schechtman who defends what she calls the Narrative Self-Constitution View (Schechtman 1996, 93-135). Much like Ganeri's performativist theory which identifies the self as the activity of appropriation, Schechtman stresses the equally strong claim that selves are constituted by their narratives. The basic claim of Schechtman's Narrative Self-Constitution View is that "we constitute ourselves as selves by understanding our lives in narrative form and living accordingly" (Schechtman 2011, 398). Despite the strong main thesis that the self is constituted by narrative, the specific claims she makes in articulating and defending the main thesis turn out to be rather modest. For example, she is quick to point out that her view does not require each individual to self-consciously and explicitly tell a story of their life. Instead, the narratives are, as she says, "largely implicit and automatic" (Schechtman 2007, 162). Also, despite the strong thesis that selves are constituted by their narratives, it is not the case that anything goes. Schechtman insists that there are constraints on self-constitution: first, an articulation constraint which is the modest requirement that one be able to "articulate one's narrative locally where appropriate" (Schechtman 2011, 405) and second, a reality constraint, which means that one's narrative should conform to society's general conception of reality (Schechtman 2011, 405). Finally, it is also important to stress that unlike some narrative theorists such as Alasdair MacIntyre and Charles Taylor whose interest in defending a robust ethical conception of the self leads them to require a thick conception of the good, Schechtman grants that her account is not strongly evaluative nor is its focus the ethical orientation of the self.

When we compare Schechtman's Narrative Self-Constitution View with accounts of narrative developed by Kierkegaardians such as John Davenport and Anthony Rudd we should not be surprised by some radical differences. Anthony Rudd, for example, sums up his Kierekgaardian approach to the question of narrative and selfhood with the acronym NEST which stands for Narrative, Evaluative, SelfConstitution and Teleology (Rudd 2012, 2). As the four key features of his thesis indicate, he shares with Schechtman the basic claim that selves are constituted by their narratives but adds that this requires that one balance the demands of selfacceptance with the demands of self-shaping. What distinguishes Rudd's Kierekegaardian account from Schechtman's view is his insistence that a coherent narrative requires a robust ethical orientation based on a teleological conception of the self. In this respect, his self-constitution account of narrative bears a stronger 
resemblance to the account developed by MacInytre in After Virtue than to Schechtman's view. Unlike MacIntyre, however-known for famously taking Aristotle as his point of departure-Rudd takes his inspiration from Kierkegaard whose theory of selfhood, he argues, is based on a Platonic teleology. So although Rudd accepts the self-constitution view, as a Kierkegaardian he wishes to accentuate Anti-Climacus's claim that the activity of narrative appropriation whereby one becomes a self is not autonomous, nor is the self's goal a natural one. According to Rudd, it is the quest for the Good, understood in Platonic terms, that underlies AntiClimacus's insistence upon a Christian framework for self-making.

What role might narrative play in attempts to spell out the implications of Ganeri's performativist theory from a Buddhist perspective? As it turns out, several recent thinkers have discovered that narrative provides perhaps the best and most natural way to articulate the Buddhist insight that the self is a conventional construction that arises simply insofar as it just is the ongoing activity of appropriation. In a recent book Engaging Buddhism, for example, Jay Garfield suggests that this ongoing activity of appropriation unfolds in the process of selfshaping narratives that give rise to our being as ethical agents:

This is because from any Buddhist perspective...persons are constructed. They are constructed through the appropriation of aggregates, through recognizing a body as mine, thought as mine, values, dispositions, and intentions as mine. In turn, those physical and cognitive processes are also constructed in relation to that person, and the person is appropriated by them as a locus. That appropriation and construction is itself accomplished through the narration of a life in which a person emerges as a character (Garfield 2015, 293).

Garfield goes on to note several points with which Kierkegaardians would likely agree. First, he stresses that the activity of appropriation that unfolds in our narratives always takes place in a social context in our relations with others. We do not spin our narratives in isolation. Given our ongoing dependence on others, our narratives unfold in our ongoing responses to the events and people around us. In addition, Garfield emphasizes a central point made by most Kierkegaardian defenders of narrative theory; namely, that narrative is a crucial dimension of ethics insofar as it is narrative that provides the basic framework for understanding and evaluating actions. Garfield stresses, however, that we must guard against reducing Buddhist ethics to those moral theories and categories familiar to us from the western tradition. Instead, we should view the narratives that frame our moral decisions as providing ways to "help us to better see how we could participate in further narratives in which we would like to figure, narratives of greater happiness, of less suffering, of more human flourishing" (Garfield 2015, 294).

\section{CONCLUSION}

One might be tempted to conclude here with a simple either/or. Of course, such an ultimatum might make sense if our aim were simply to articulate a choice between 
nirvana and Kierkegaard's paradoxical Christianity. With all due respect to Judge William, however, even though the imperative to "choose oneself" might have its proper place in the appropriate existential situation, when it comes analyzing the self, the options are not so clear. As we have seen, debates about the self among Buddhists and Kierkegaardians reveal that it is a contested notion. And although both Buddhists and Kierkegaardians might find common ground in Ganeri's performativist theory of the self, questions remain about the role of narrative in the activity of selfappropriation. So even if we have not settled the question of whether we should follow Kierkegaard and regard the self as a task, perhaps we can at least agree that understanding the self remains a task for us.

\section{ACKNOWLEDGEMENTS}

This article began as a presentation to the "Kierkegaard, Religion, and Culture Group and Yogācāra Studies Group" at the November 2015 annual meeting of American Academy of Religion held in Philadelphia. I would like to express my appreciation for the feedback at the meeting. In addition, I would like to thank an anonymous referee from Comparative Philosophy for helpful comments and suggestions.

\section{REFERENCES}

Candrakīrti (2002), Introduction to the Middle Way: Madhyamakāvatāra, trans. Helena Blankleder and Wultsan Fletcher (Boston and London: Shambhala).

Conze, Edward (1973), Perfect Wisdom: The Short Prajñāpāramitā Texts (Totnes: Buddhist Publishing Group).

Davenport, John J. (2013), "Selfhood and 'Spirit", in John Lippitt and George Pattison (eds), The Oxford Handbook of Kierkegaard (New York: Oxford University Press), 230-251.

Davenport, John. J. and Rudd, Anthony (eds) (2002), Kierkegaard After MacIntyre (Chicago: Open Court).

Dreyfus, Herbert L (2008), "Kierkegaard on the Self", in Edward Mooney (ed.), Ethics, Love, and Faith in Kierkegaard (Bloomington: Indiana University Press), 12-23.

Dunning, Stephen (1985), Kierkegaard's Dialectic of Inwardness: A Structural Analysis of the Stages (Princeton: Princeton University Press).

Edgerton, Franklin (1953), Buddhist Hybrid Sanskrit: Vol. II Dictionary (New Haven: Yale University Press).

Elrod, John W. (1975), Being and Existence in Kierkegaard's Pseudonymous Works (Princeton: Princeton University Press).

Ganeri, Jonardon (2012), The Concealed Art of the Soul: Theories of Self and Practices of Truth in Indian Ethics and Epistemology (New York: Oxford University Press). 
Garfield, Jay L. (1995), The Fundamental Wisdom of the Middle Way: Nāgārjuna's Mūlamadhyamakakārikā (New York: Oxford University Press).

- (2015), Engaging Buddhism: Why It Matters to Philosophy (New York: Oxford University Press).

Grøn, Arne (2004), "Self and Identity", in Dan Zahavi, Thor Grünbuam and Josef Parnas (eds.), The Development and Structure of Self-Consciousness (AmsterdamPhiladelphia: John Benjamins), 123-156.

Hannay, Alastair (1982), Kierkegaard (London: Routledge).

Kierkegaard, Søren (1989), The Sickness Unto Death: A Christian Psychological Exposition for Edification and Awakening, trans. Alastair Hannay (New York: Penguin Books).

- (1990), Eighteen Upbuilding Discourses, trans. Howard V. Hong and Edna H. Hong (Princeton: Princeton University Press).

- (1992), Concluding Unscientific Postscript, trans. Howard V. Hong and Edna H. Hong (Princeton: Princeton University Press).

- (2009), Concluding Unscientific Postscript to the Philosophical Crumbs, ed. and trans. Alastair Hannay (Cambridge: Cambridge University Press).

Korsgaard, Christine M. (2009), Self-Constitution: Agency, Identity, and Integrity (New York: Oxford University Press).

MacIntyre, Alasdair (2002), After Virtue, $2^{\text {nd }}$ ed. (Notre Dame: University of Notre Dame Press).

Mackey, Louis (1971), Kierkegaard: A Kind of Poet (Philadelphia: University of Pennsylvania Press).

Malantschuk, Gregor (1971), Kierkegaard's Thought, trans. Howard V. Hong and Edna H. Hong (Princeton: Princeton University Press).

Mooney, Edward (1996), Selves in Discord and Resolve: Kierkegaard's MoralReligious Psychology from Either/Or to Sickness Unto Death (New York: Routledge).

Ricoeur, Paul (1984-1988), Time and Narrative, 3 vols. trans. Kathleen Blamey and David Pellauer (Chicago: University of Chicago Press).

Rudd, Anthony (2012), Self, Value, \& Narrative: A Kierkegaardian Approach (New York: Oxford University Press).

Schechtman, Marya (1996), The Constitution of Selves (Ithaca, Cornell University Press).

- (2007), "Stories, Lives, and Basic Survival: A Refinement and Defense of the Narrative View", in Daniel D. Hutto (ed.), Narrative Understanding and Persons (Cambridge: Cambridge University Press).

- (2011), “The Narrative Self”, in Shaun Gallagher (ed.), The Oxford Handbook of the Self (New York: Oxford University Press).

Siderits, Mark (2007), Buddhism as Philosophy: An Introduction (Indianapolis: Hackett Publishing).

Stokes, Patrick (2010), Kierkegaard's Mirrors: Interest, Self, and Moral Vision (New York: Palgrave Macmillan). 
- (2015), The Naked Self: Kierkegaard and Personal Identity (New York: Oxford University Press).

Taylor, Charles (1989), Sources of Self: The Making of Modern Identity (Harvard University Press).

Taylor, Mark C. (1980), Journeys to Selfhood: Hegel and Kierkegaard (Berkeley: University of California Press).

Turnbull, Jamie (2011), "Saving Kierkegaard's Soul: From Philosophical Psychology to Golden Age Soteriology", in Jon Stewart, Heiko Schultz and Karl Verstrynge (eds), Kierkegaard Studies Yearbook 2011 (Berlin: de Gruter), 279-302.

Williams, Paul (2009), Māhāyana Buddhism: The Doctrinal Foundations, $2^{\text {nd }}$ ed. (New York: Routledge).

Williams, Paul, Tribe, Anthony and Wynne, Alexander (2012), Buddhist Thought: A Complete Introduction to the Indian Buddhist Tradition, $2^{\text {nd }}$ ed. (New York: Routledge). 